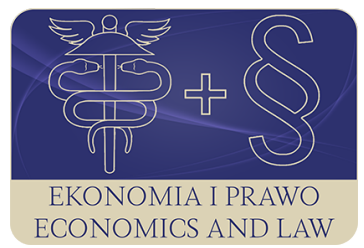

EKONOMIA I PRAWO. ECONOMICS AND LAW

Volume 16, Issue 2, June 2017

p-ISSN 1898-2255, e-ISSN 2392-1625

www.economicsandlaw.pl

ORIGINAL ARTICLE

received 13.06.2017; revised 25.06.2017; accepted 30.06.2017

Citation: Żemigała, M. (2017). Application of Social Responsibility standards in Poland and the World. Ekonomia i Prawo. Ecomomics and Law, 16(2): 229-240. doi:10.12775/EiP.2017.016.

\title{
Application of Social Responsibility standards in Poland and the World
}

\author{
MARCIN ŻEMIGAEA \\ University of Warsaw, Faculty of Management, Department of Organization and Management \\ Theory, ul. Szturmowa 1/3, 02-678 Warsaw, Poland \\ 曰m.zemigala@poczta.onet.pl
}

\begin{abstract}
Motivation: Social responsibility (SR) is a management concept that is similar to quality management and environmental management. Like every concept, it has a set of tools that can be implemented in organizations that need to use the concept in their activities. Currently, the SR tool catalog is being modified and keeps growing. Two research questions were stated: (1) How does the use of SR standards look like in the world according to current data? (2) How does the use of SR standards look like in individual countries and in Poland according to current data?

Aim: The purpose of this article is to analyze the use of standardized SR tools. The essence of SR was first approximated and a set of standardized tools was characterized. The state of their application was analyzed empirically.

Results: The most commonly used SR standard is ISO 14001, the others are less commonly used. On the one hand, it is comforting that a voluntary environmental norm is relatively common; on the other hand, it is surprising that tools from other spheres (working conditions, sustainability reporting and stakeholder relations) have little use. With regard to the use of standardized SR tools in different countries, there is a strong tendency among non-developed and stable economies to use these tools, which demonstrates their greater motivation to improve competitiveness with the use of SR. Unfortunately, in Poland this trend does not exist and the analyzed standards are practically not used, except for ISO 14001.
\end{abstract}

Keywords: social responsibility; standardized tools of social responsibility; application of social responsibility

JEL: M14; M16 


\section{Introduction}

The organization's social responsibility (SR) is one of the newer management concepts that is beginning to develop similarly to quality management and environmental management. Like every concept, it has a set of tools that can be implemented in organizations that need/have to use a given concept in their activities. Currently, the catalog of SR tools is being modified and keeps growing, giving potential users better opportunities to shape (react, prevent, reinforce) relationships with the surrounding world in a social perspective. Like every concept, SR is built around specific values. In the case of quality management, such a superior value is excellence and striving for it by improvements, in the case of environmental management the overriding is the environment and care for its current and future state. As far as SR is concerned, the focus is on the relationships between organization and society (Porter \& Kramer, 2006, pp. 78-92) and it is the society (state and prospects in the future of the whole society and its individual groups) that the overriding value of this concept can be recognized.

The aim of the article is to approximate the essence of SR, to characterize a set of standardized SR tools, and to analyze the state of their application. Two research questions were formulated and a set of data for the four SR tools was identified: ISO 14001, SA 8000, AA 1000AS and G4.

\section{Tools of Social Responsibility}

By analyzing the meaning of SR, some of its distinguishing features can be specified. First of all, as most of the management concepts, SR is voluntary - it is applied in the case of perception of the premises, eg.: the need to prevent certain negative phenomena in the relation with the social environment (preventive actions); wishing to fix the damage done to certain areas of this environment (reactive actions) or to obtain greater benefits (strategic actions). Secondly, SR does not restrict itself to companies but covers all types of organizations. In the older publications, the prospect of large enterprises was dominating (with regard to companies, it is referred to as Corporate Social Responsibility CSR) (Fischer \& Groenveld, 1976, pp. 18-26), while other types of business organizations (eg.: SMEs) were rarely taken into account (Chrisman \& Archer, 1984, pp. 46-58; Wilson, 1980, pp. 17-24). Currently, SR takes into account all types of enterprises (Jenkins, 2006, pp. 241-256; Russo \& Perrini, 2010, pp. 207-221) and more broadly, all types of organized activities, such as public organizations (Enticott \& Walker, 2008, pp. 79-92; Heath \& Norman, 2004, pp. 247-265). Thirdly, SR is a concept applied to organizations operating in a market environment. It is therefore unreasonable to put in opposition to SR the principles of free market economy, rational management of financial resources or (in the case of enterprises) profit maximization, as already shown in 1979 by A.B. Carroll in his pyramid of responsibility, where the foundation 
is precisely the economic responsibility (Carroll, 1979, pp. 497-505; Schwartz \& Carroll, 2003, pp. 503-530). Fourth, SR grows out of R.E. Freeman's stakeholder theory which consists in analyzing the needs and expectations of various groups of interest in relation to the organization (Freeman, 1984, p. 38; Freeman et al., 2004, pp. 364-369).

However, the rooting of SR in previous stakeholder theory does not provide sufficient possibilities for its application. This problem is solved by a catalogue of tools that allow the implementation. Just as tools within other concepts, also those related to SR are oriented around its core values. There are two types of such tools. Firstly, initiatives/programs (non-standardized tools) that usually contain fairly general sets of principles or guidelines, their use is less formal and gives greater opportunity for subjective approaches and interpretations. Secondly, the norms (standards), which are more formalized and specific, force better integration of SR activities and management systems. Both standards and initiatives can be divided into those for use in organizations of all types and segments (universal) and those designed for specific market segments and types of organizational activities (Żemigała, 2013, pp. 49-50).

Due to the greater degree of formalization and rooting in management systems, further analyzes will be devoted to universal standardized tools, which include:

- Standards AA 1000. The family of standards consists of three international norms. AA 1000 APS, which specifies three principles (AccountAbility, 2008a, pp. 10-16): inclusivity, materiality, and responsiveness. Another norm, AA 1000 AS, is devoted to checking whether the organization has implemented the principles listed in the AA 1000 APS in the appropriate, standardized way (AccountAbility, 2008b, pp. 9-22). The AA 1000 SES contains information on how to involve stakeholders in the organizations' activities. It offers in its content a process of such activities ranging from planning, preparation through implementation, review and improvement (Account Ability, 2015a, pp. 22-43) (scheme 1.).

- Norm SA 8000. This is an international system standard for working conditions. It was developed on the basis of a series of International Labor Organization's conventions. Its structure (scheme 2.) consists of eight technical modules and a ninth system module, which is designed to merge, to integrate the previous elements into one whole (SAI, 2008, pp. 8-16).

- Norm ISO 14001. This is the only standard out of the ISO 14000 family that is intended for certification purposes. This international standard provides guidelines for organizations of any type that facilitate the design, implementation, maintenance and improvement of an environmental management system. Continuous improvement is one of the most important elements of this standard, as the whole standard is based on Deming's continuous improvement cycle (scheme 3.) (PKN, 2015, p. vii).

- Norm ISO 26000. This is an international standard that applies to any type of organization, similarly to ISO 14001 and ISO 9001. However, un- 
like them, it is not intended for certification purposes and it is not a norm of management system. ISO 26000 contains information to help organizations understand what SR is and what its relationship to sustainable development is (PKN, 2012, p. 11).

- G4 standards. International reporting standards for sustainability, developed by the Global Reporting Initiative, consist of reporting principles (regarding content and quality), indicators (48 profile and 92 detail), and guidance manual (GRI, 2016b, pp. 16-18, 24-83).

\section{Methods}

In the light of the presented standardized tools of SR, two research questions were stated:

- RQ1: How does the use of SR standards look like in the world according to current data?

- RQ2: How does the use of SR standards look like in individual countries and in Poland according to current data?

The analytical data required for completeness and reliability are neccessary to answer these research questions. These two conditions meet the data coming from organizations formally responsible for the analyzed standards (table 1).

This type of data has several limitations that need to be specified:

- Data comes from different sources.

- The most up-to-date and complete data come from different periods, from late 2014 to July 2016.

- Data was collected without the use of a single procedure, each organization conducting its own research was taking the most appropriate steps.

Given the above, the presented analyzes are of an illustrative nature, give a general tendency in the application of the analyzed standards. However, it should be emphasized that they are based on data from official sources that can be considered reliable and complete. No other sources have been identified to provide more comprehensive data on the area under investigation.

Four standards were included in the further analysis: ISO 14001, SA 8000, AA 1000 AS and G4; however, ISO 26000 was not included due to the nature of the norm (not for certification) and therefore no relevant data.

\section{Results}

By analyzing the data set in the context of RQ1, it turns out that the most popular SR standard is the Environmental Management System according to ISO 14001. The total number of applications in the analyzed dataset is 324148 . None of the other standards came even close to a similar result. The popularity of ISO 14001 can be attributed to the reputation of the International Organization for Standardization (ISO). In addition, the quality management standard ISO 9001 on which the ISO 14001 standard was based has also been very well received by 
organizations. Another reason for the large number of applications of ISO 14001 is the frequent path of implementation of management systems, the first is usually the quality management system (oftentimes, ISO 9001 is chosen) and then the environmental management system (in this case, the organizations that have tested ISO 9001 choose ISO 14001). These facts allow to claim with a degree of certainty that if ISO 26000 is reformulated for certification in the future, it will also become very popular.

Other SR standards have been much lower in terms of applications. None of the standards exceeded 2\% of ISO 14001, the closest to this threshold is the SA 8000 standard with 3757 applications at a percentage of just over 1\% of ISO 14001. The next two standards have achieved even lower scores (table 2).

By analyzing the dataset for RQ2 responses, it is clear that in terms of implementation of ISO 14001 the leading country is China with a percentage share of more than 36\%, no other country has received a double-digit rate. Out of the Eastern European countries, only Romania was on the list of the top ten countries using ISO 14001. Surprisingly, the developed countries and large European economies are further placed on the list, such as Great Britain (4th place), France (7th) and Germany (8th). The second most popular standard SA 8000 is most commonly used in Italy and India with the absence of representatives of large developed European economies in the top ten. Romania is again emerging as a representative of Eastern European countries, followed by Bulgaria. Taking into account the application of the G4 standards in the top ten countries, more representatives of Western Europe have been noted; Finland comes as first and Switzerland, Germany, the United Kingdom and Sweden are also included. Only within the scope of application of this particular standard, the United States has taken the top position, which in other cases occupies further places. However, it should be noted that the $\mathrm{G} 4$ is much less popular standard than the previous ones. The least popular, AA 1000 AS standard, is most commonly applied in South Korea, India and the United Kingdom. A detailed breakdown of the first ten countries in terms of application of the standards is presented in table 3 . The overall conclusion of this analysis is that countries with economies recognized as developed, stable and with great traditions do not rank prominently. On the other hand, the ranking includes countries like China, India, Mexico and South Korea. This may indicate that in countries where economies are actually stabilized, organizations do not see the need to improve their competitive position by using SR tools. Wherever the economy is developing or facing various crises, it is possible to find market opportunities by applying the analyzed standards. This is the case, for example, in China (environmental issues and the popularity of ISO 14001, labor standard issues and SA 8000), India (labor standards - SA 8000), Japan (environmental protection). It is also evident that Eastern European countries have little use of these tools. Romania appears twice in the list of top ten countries (ISO 14001 and SA 8000) and Bulgaria once (SA 8000). Poland achieves very poor results, as shown in table 4. Basically, it can be said that the application of standardized SR tools 
in Poland is absent, with the exception of ISO 14001, but the implementation is a fraction of a percentage of the total number of implementations in the world. Such a picture can be astonishing, Poland is neither a developed economy nor strong enough not to seek new opportunities for development; it also faces environmental problems, as well as working condition, sustainability reporting or stakeholder relation issues.

\section{Conclusion}

Concluding the analysis on the above topic, several aspects can be highlighted. SR is a management concept with a set of tools, including standardized tools. The most commonly applied standard is the Environmental Management System according to ISO 14001, further standards are much less frequently used. On the one hand, it is comforting that a voluntary environmental management standard is relatively common, but on the other hand, it is surprising that tools from other thematic areas (working conditions, sustainable development reporting and stakeholder relations) have little application. With regard to the use of standardized SR tools in different countries, a strong tendency is noted among non-developed countries and stable economies to use the analyzed tools; it is an evidence that they are motivated to improve their competitiveness by using SR as well. Unfortunately, in Poland such tendency does not exist and the analyzed standards are practically not used, except for ISO 14001.

\section{References}

AccountAbility. (2008a). AA 1000 accountability principles standard. Retrieved 02.05.2017 from http://www.accountability.org.

AccountAbility. (2008b). AA 1000 assurance standard. Retrieved 02.05.2017 from http://www.accountability.org.

AccountAbility. (2015a). AA1000 stakeholder engagement standard. Retrieved 02.05.2017 from http://www.accountability.org.

AccountAbility. (2015b). Retrieved 02.05.2017 from: http://www.accountability.org.

Carroll, A.B. (1979). A three - dimensional conceptual model of corporate performance. Academy of Management Review, 4(4). doi:10.2307/257850.

Chrisman, J.J., \& Archer, R.W. (1984). Small business social responsibility: some perceptions and in-sights. American Journal of Small Business, 9(2).

Enticott, G., \& Walker, R.M. (2008). Sustainability, performance and organizational strategy: an empirical analysis of public organizations. Business Strategy and the Environment, 17(2). doi:10.1002/bse.501.

Fischer, W.A., \& Groenveld, L. (1978). Social responsibility and small business. Journal of Small Busi-ness Management, 14(1).

Freeman, R.E. (1984). Strategic management: a stakeholder approach. Boston: Pitman. 
Freeman, R.E., Wicks, A.C., \& Parmar, B. (2004). Stakeholder theory and 'the corporate objective revis-ited'. Organization Science, 15(3). doi: 10.1287 /orsc. 1040.0066 .

GRI. (2016a). Retrieved 02.05.2017 from: https://www.globalreporting.org/ services/Analysis/Reports_List/Pages/default.aspx.

GRI. (2016b). Wytyczne do raportowania. Retrieved 02.05.2017 from http://odpowiedzialnybiznes.pl.

Heath, J., \& Norman, W. (2004). Stakeholder theory, corporate governance and public management: what can the history of state-run enterprises teach us in the post-Enron era? Journal of Business Ethics, 53(3). doi: 10.1023/B:BUSI.0000039418.75103.ed.

ISO. (2014). Retrieved 02.05.2017 from: http://www.iso.org/iso/iso-survey.

Jenkins, H. (2006). Small business champions for corporate social responsibility. Journal of Business Ethics, 67(3). doi: 10.1007/s10551-006-9182-6.

PKN. (2012). Wytyczne dotyczące spotecznej odpowiedzialności (PN-ISO 26000). Retrieved 02.05.2017 from https://www.pkn.pl.

PKN. (2015). Systemy zarzadzania środowiskowego. Wymagania i wytyczne stosowania (PN-EN ISO 14001:2015). Retrieved 02.05.2017 from https://www. pkn.pl.

Porter, M.E. \&, Kramer, M.R. (2004). Strategy and society. Harvard Business Review, 84(12).

Russo, A., \& Perrini, F. (2010). Investigating stakeholder theory and social capital: CSR in large firms and SMEs. Journal of Business Ethics, 91(2). doi: 10.1007/s10551-009-0079-z.

SAI. (2008). Social accountability 8000. Retrieved 02.05.2017 from http:// www.sa-intl.org.

Social Accountability Accreditation Services. (2016). Retrieved 02.05.2017 from: www.saasaccreditation.org/sites/default/files/u4/Q1_2016_SAAS_ SA8000_public_list.xlsx.

Schwartz, M.S., \& Carroll, A.B. (2003). Corporate social responsibility: a three-domain approach. Business Ethics Quarterly, 13(4).

Wilson, E. (1980). Social responsibility of business: what are the small business perspectives? Journal of Small Business Management, 3.

Żemigała, M. (2013). Spoteczna odpowiedzialność biznesu w świetle analiz bibliometrycznych $i$ opinii pracowników na temat równowagi między życiem zawodowym a prywatnym. Warszawa: Wydawnictwo Naukowe Wydziału Zarządzania Uniwersytetu Warszawskiego. 


\section{Acknowledgements}

Author contributions: author has given an approval to the final version of the article.

Funding: this research was undertaken as part of the Analizy wspótczesnych koncepcji zarządzania środowiskowego i zarządzania jakościa project and was jointly funded by a grant to maintain research capacity at the Faculty of Management, University of Warsaw (Ministry of Science and Higher Education).

Note: the results of this study were presented at 9th International Conference on Applied Economics Contemporary issues in Economy (Toruń, June 22-23, Toruń, Poland). 


\section{Appendix}

Table 1.

Details of analytical data

\begin{tabular}{|c|c|c|c|c|}
\hline No. & Standard & $\begin{array}{l}\text { Responsible } \\
\text { organization }\end{array}$ & Data source & Update \\
\hline 1 & SA 8000 & $\begin{array}{l}\text { SAI - Social } \\
\text { Accountability } \\
\text { International }\end{array}$ & $\begin{array}{l}\text { Data provided by Social Accountability Accreditation Services } \\
\qquad(2016) .\end{array}$ & $\begin{array}{c}\text { As } \\
\text { of } 31.03 .16\end{array}$ \\
\hline 2 & AA 1000 & AccountAbility & $\begin{array}{l}\text { Data provided by AccountAbility (2015b). } \\
\text { They apply to AA } 1000 \text { AS certified by licensed by AccountA- } \\
\text { bility certification organizations. }\end{array}$ & $\begin{array}{l}\text { End } \\
\text { of } 2015\end{array}$ \\
\hline 3 & $\begin{array}{l}\text { ISO } \\
26000\end{array}$ & $\begin{array}{l}\text { ISO - In- } \\
\text { ternational } \\
\text { Organization for } \\
\text { Standardization }\end{array}$ & $\begin{array}{l}\text { Due to the fact that ISO } 26000 \text { is currently not intended for } \\
\text { certification purposes, there is no such data. }\end{array}$ & - \\
\hline 4 & $\begin{array}{l}\text { ISO } \\
14001\end{array}$ & $\begin{array}{l}\text { ISO - In- } \\
\text { ternational } \\
\text { Organization for } \\
\text { Standardization }\end{array}$ & $\begin{array}{c}\text { Data from ISO surveys includes these certifications by bodies } \\
\text { accredited by the International Accreditation Forum. Data } \\
\text { retrieved from ISO (2014) }\end{array}$ & $\begin{array}{l}\text { End } \\
\text { of } 2014\end{array}$ \\
\hline 5 & G4 & $\begin{array}{l}\text { GRI - Global } \\
\text { Reporting } \\
\text { Initiative }\end{array}$ & Data from GRI (2016a) analysis. & $\begin{array}{c}\text { As } \\
\text { of } 01.06 .16\end{array}$ \\
\hline
\end{tabular}

Note:

All data collected on July 28, 2016.

Source: Own preparation.

Table 2.

Application of standards

\begin{tabular}{ccc}
\hline Standard & Number of applications & Percentage \\
\hline ISO 14001 & 324148 & 100.00 \\
SA 8000 & 3757 & 1.16 \\
G4 & 459 & 0.14 \\
AA 1000 AS & 125 & 0.04 \\
\hline
\end{tabular}

Note:

In the column 'Percentage', 100\% is considered the total amount of ISO 14001 applications.

Data in the G4 line relates only to those reports that have been prepared in strict accordance with its guidelines, including those prepared in previous versions (G3 and G3.1) which have not yet expired and are not required to be changed (there were 11 such reports).

Source: Own preparation based on data like in table 1. 
Table 3.

Application of SR standards in individual countries

\begin{tabular}{|c|c|c|c|c|}
\hline Standard & No. & Country & Number of applications & Percentage \\
\hline \multirow{10}{*}{ ISO 14001} & 1 & China & 117758 & 36.33 \\
\hline & 2 & Italy & 27178 & 8.38 \\
\hline & 3 & Japan & 23753 & 7.33 \\
\hline & 4 & Great Britain & 16685 & 5.15 \\
\hline & 5 & Spain & 13869 & 4.28 \\
\hline & 6 & Romania & 9302 & 2.87 \\
\hline & 7 & France & 8306 & 2.56 \\
\hline & 8 & Germany & 7708 & 2.38 \\
\hline & 9 & USA & 6586 & 2.03 \\
\hline & 10 & India & 6446 & 1.99 \\
\hline \multirow{10}{*}{ SA 8000} & 1 & Italy & 1224 & 32.58 \\
\hline & 2 & India & 1112 & 29.60 \\
\hline & 3 & China & 661 & 17.59 \\
\hline & 4 & Vietnam & 112 & 2.98 \\
\hline & 5 & Romania & 97 & 2.58 \\
\hline & 6 & Bulgaria & 70 & 1.86 \\
\hline & 7 & Pakistan & 59 & 1.57 \\
\hline & 8 & Brazil & 51 & 1.36 \\
\hline & 9 & Portugal & 38 & 1.01 \\
\hline & 10 & Taiwan & 37 & 0.98 \\
\hline \multirow{10}{*}{ G4 } & 1 & Finland & 72 & 15.69 \\
\hline & 2 & USA & 43 & 9.37 \\
\hline & 3 & Mexico & 35 & 7.63 \\
\hline & 4 & Switzerland & 22 & 4.79 \\
\hline & 5 & Germany & 20 & 4.36 \\
\hline & 6 & Singapore & 20 & 4.36 \\
\hline & 7 & Turkey & 17 & 3.70 \\
\hline & 8 & Great Britain & 16 & 3.49 \\
\hline & 9 & Spain & 15 & 3.27 \\
\hline & 10 & Sweden & 13 & 2.83 \\
\hline \multirow{10}{*}{ AA 1000 AS } & 1 & South Korea & 41 & 32.80 \\
\hline & 2 & India & 13 & 10.40 \\
\hline & 3 & Great Britain & 11 & 8.80 \\
\hline & 4 & Spain & 6 & 4.80 \\
\hline & 5 & Indonesia & 5 & 4.00 \\
\hline & 6 & RSA & 5 & 4.00 \\
\hline & 7 & Italy & 4 & 3.20 \\
\hline & 8 & Switzerland & 4 & 3.20 \\
\hline & 9 & Taiwan & 4 & 3.20 \\
\hline & 10 & Finland, Russia, Sri Lanka & 3 & 2.40 \\
\hline
\end{tabular}

Note:

For each standard, data is provided for the top 10 countries with the highest number of applications. In the columns ,Percentage', $100 \%$ is considered the total amount of uses of a particular standard. Source: Own preparation based on data like in table 1. 
Table 4.

Application of SR standards in Poland

\begin{tabular}{ccc}
\hline Standard & Number of application & Percentage \\
\hline ISO 14001 & 2213 & 0.68 \\
SA 8000 & 9 & 0.24 \\
G4 & 2 & 0.44 \\
AA 1000 AS & 0 & 0.00 \\
\hline
\end{tabular}

Note:

$100 \%=$ total number of uses per standard.

Source: Own preparation based on data like in table 1.

\section{Scheme 1.}

\section{AA 1000 SES steps}

Profiling \& mapping stakeholders. Determining engagement levels \& methods \& boundaries of disclosure. Draft engagement plan and indicators for evaluation

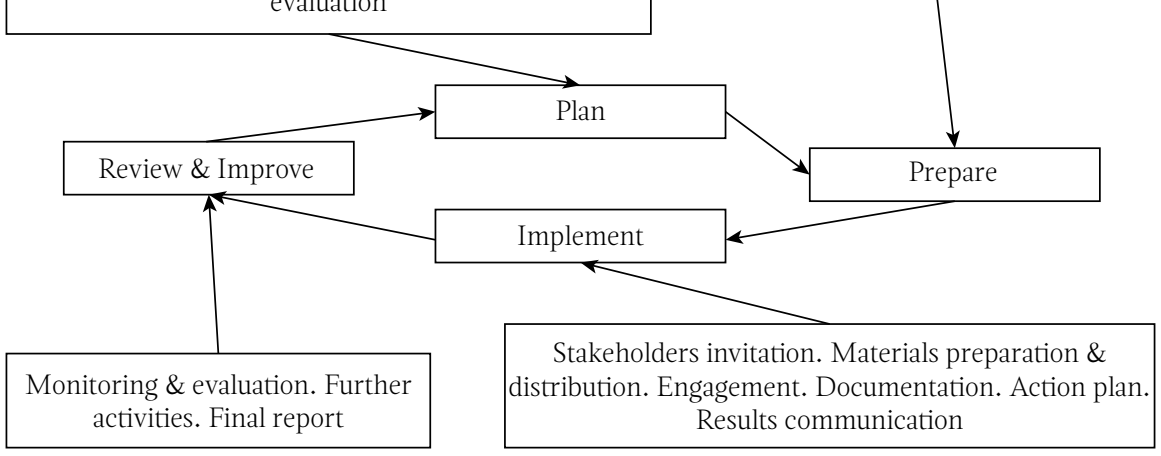

Source: Own preparation based on AccountAbility (2015a, pp. 22-43). 
Scheme 2.

SA 8000 structure

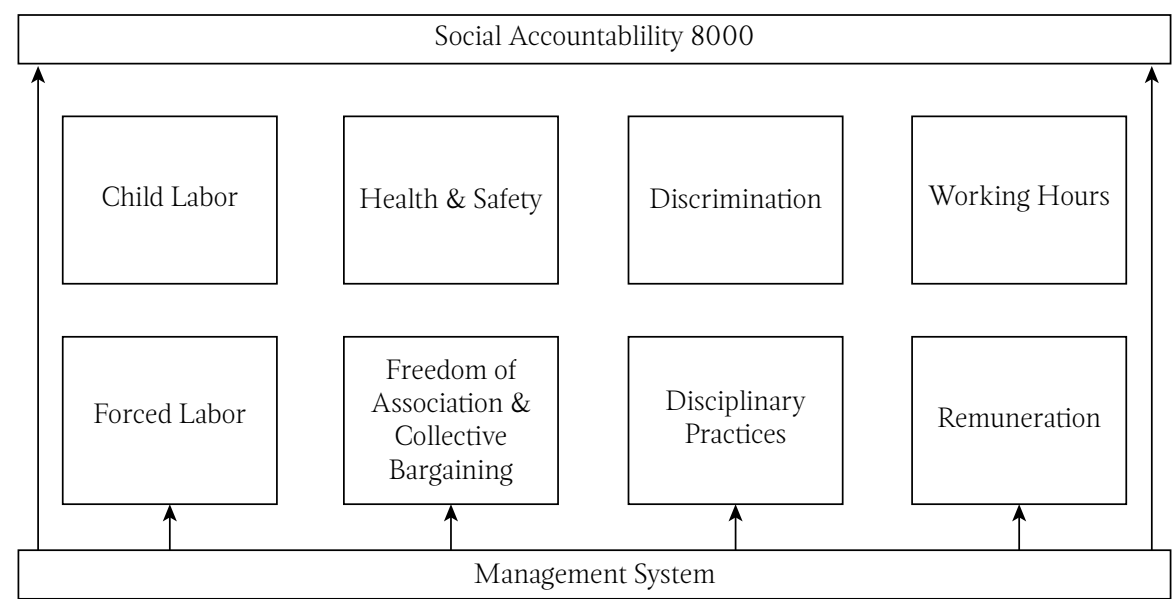

Source: Own preparation based on SAI (2008, pp. 8-16).

Scheme 3.

Environmental Management System (EMS) according to ISO 14001 in the perspective of Deming's cycle

Internal \& external issues

Stakeholders' needs \& expectations

Context of the organization

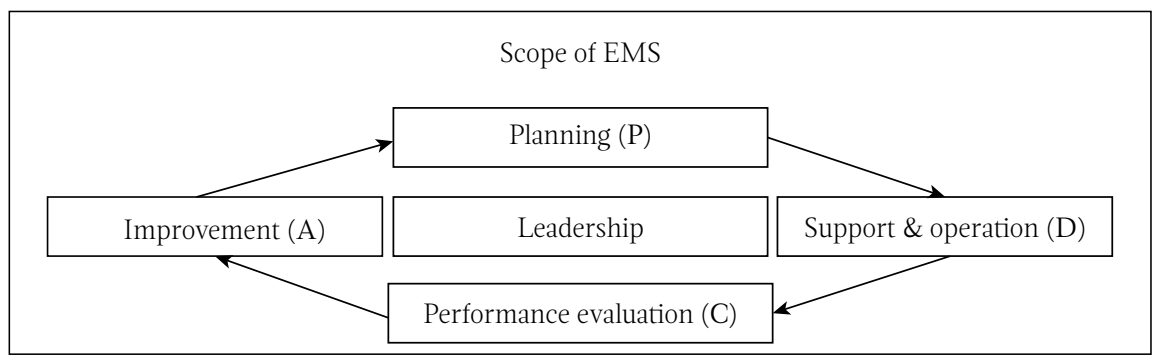

Outcomes of EMS

Source: PKN (2015, p. vii). 